\title{
Integrating Nonviolent Communication in Performing Arts to Counter Narratives of Hate
}

\author{
Vedabhyas Kundu \\ Programme Officer, Gandhi Smriti and Darshan Samiti, Rajghat, New Delhi, India \\ Corresponding author: vedabhyas@gmail.com
}

Received: 11 July, 2019

Revised: 09 Oct., 2019

Accepted: 26 Nov., 2019

\begin{abstract}
The increase in narratives of hatred across the world poses a major challenge for governments and civil societies across the world. While number of initiatives can be taken to counter the demonizing effect of hate narratives, performing arts can play a significant role in arousing public sentiments against such narratives and facilitate social harmony. Performing arts have a history of contributing to peace-building and reconciliation. The challenge, however, is on the type and nature of messages that needs to be constructed in performing arts to influence the audience. An important strategy could be to use tools of nonviolent communication while developing performances- be it theatre, music, street plays, etc. This chapter delves on the centrality of nonviolent communication in performing arts to not only counter narratives of hatred but also promote reconciliation and social harmony.
\end{abstract}

Keywords: Nonviolent communication, performing arts, hate narratives, reconciliation, peace-building

At a time when hate narratives seems to be on the rise across the world, it is a challenge before governments, the civil society and the citizenry at large to think out of the box strategies to counter these narratives. As a response to the rise in hate speech, the United Nations in 2019 launched a UN Strategy and Plan of Action on hate speech.

The UN Strategy and Plan of Action provides a system-wide programme with the overriding objective of identifying, preventing and confronting hate speech, the U N Secretary-General António Guterres said while launching the Plan of Action. (Guterres, 2019)

It targets the root causes of hate speech, Guterres said, pointing out that these include tackling violence, marginalization, discrimination, and poverty, as well as bolstering weak state institutions.
He said the strategies included 'bringing individuals and groups together who have opposing views; working with traditional and social media platforms; and developing communications guidance'.

Guterres argued, "We should treat it like any other malicious act: by condemning it unconditionally; refusing to amplify it; countering it with the truth; and encouraging the perpetrators to change their behaviour." The UN Secretary General's stress on the need to treat hate speech like any other malicious act underscores the need for a global effort to encourage positive narratives at a global level and in every communities.

\footnotetext{
How to cite this article: Kundu, V. (2019). Integrating Nonviolent Communication in Performing Arts to Counter Narratives of Hate. Int. J. Peace, Edu. and Deve., 7(02): 95-100.

Source of Support: None; Conflict of Interest: None
} 
One of the innovative interventions that can be tried at community level to encourage counter narratives to hate speech is the strategic use of performing arts. These would include dance, music, theatre, mime, puppetry, magic, etc. Several examples from different parts of the world suggests the important role of art and culture in promoting peace and reconciliation. For performing arts to play a significant role in countering hate narratives, tools of nonviolent communication could be integrated in performances to encourage nonviolent narratives. This chapter will look at the importance of integrating nonviolent communication in performing arts for shaping counter narratives to hatred.

\section{Interventions involving Performing Arts in promoting Peace and Reconciliation}

One of the greatest genocides of human history, the Rwanda genocide of 1994 in which almost $1,000,000$ people were massacred due to the interethnic conflict between the Hutus and the Tutsis over a period of about three months was the result of the extreme hate narratives. In the post-genocide Rwanda, the government and the civil society in the country committed themselves to a variety of cultural education and extensive use of performing arts to encourage social cohesion.

Baily (2019) talks about the Never Again Rwanda initiative which 'works with those affected by the genocide and seeks to encourage 'creative, active and critical thinking' citizens through films, discussion and group work'. "Activities include storytelling, group theatre, poetry and drama, and draw upon Rwandan culture and values. Its learning approach aims to influence young people's understanding of critical thinking, values, rights, democratic principles and responsibilities," Bailey adds.

Bailey further points out, "The arts play a central role in Kwibuka, the annual commemoration of the 1994 genocide. A key focus is the Flame of Remembrance, which tours around the country each year in a similar way to the Olympic flame, with communities marking its arrival with their own ceremonies, including community performances of theatre, music and poetry. The events are designed to focus on remembrance, reconciliation and rebuilding."

Similarly, Columbia's National Batuta Foundation through its initiative Music for Reconciliation has been using music as a tool to reach out to youth helping them to rebuild social relations. According to Bailey, after the end of five decade long internal conflict, the Music for Reconciliation programme 'has helped create a sense of mutual understanding among participants from different walks of life, contributing to reconciliation'.

Another significant case shared by Bailey is The Prophecy, a Syrian theatre production staged in 2015 which reflected on the continued conflict and encouraged feelings of hope, tolerance and understanding among Syrians. She underlines the importance of art therapy for those living in conflict situations. In the context of Syrian children, she argues, "Art therapy helps improve well-being and social skills, and helps them deal with pressures and traumatic experiences, while exhibiting and selling their work builds their communication skills and bolsters self-worth."

While there would be numerous examples from around the world on how different forms of performing arts have been bringing waring groups together, promote social cohesion and help citizens deal with traumatic experiences in post-conflict situations, it would be apt to explore on how through such performances the messages of love, kindness, compassion, gratitude and mutual respect can be portrayed. In the backdrop of contentions and contestations on how art and culture can be used to fuel violence and conflicts as well as its potential to contribute towards the peace process and reconciliation, the challenge is how it's power can be strategically harnessed for social cohesion.

Citing several scholars Naidu-Silvermann (2015) argues, "One of the most important roles of art and culture in post-conflict societies is its ability to restore victims' capacities to participate in reconciliation processes, access their emotions and begin their individual healing processes. It 
Integrating Nonviolent Communication in Performing Arts to Counter Narratives of Hate 자탄

is only through creative acts that are responsive and adaptive to survivors' needs that survivors of conflict can make new meanings and create new languages to understand their reality."

Naidu-Silvermann further points out:

"Aesthetic processes such as visual art therapy and dance have the potential to overcome verbal barriers, communicating and reaching hidden emotions and feelings that everyday language is unable to bring to life....For societies emerging from conflict, the art provide a new form of communication and a creative tool to address the silences and pain that are rendered unspeakable. If opposing groups are to transcend their feelings of animosity and begin rebuilding their relationships, they require spaces that provide opportunities for discussion, dialogue and active listening."

While the arguments of Naidu-Silvermann underline the role of performing arts in peacebuilding and reconciliation, its contribution to counter hate narratives like hate speech needs to explored. This would form the basis of integrating elements of nonviolent communication in performing arts so that these form the antidote to the hate narratives.

For instance, the Council of Europe (2018) has introduced innovative ways in which young people are encouraged to 'counter hate speech in different contexts, by combining various art forms and methods such as participatory theatre, storytelling, pictures, and videos.' For instance, the Living Library is a participatory work meant to challenge prejudice, stereotypes, and discrimination, by offering the possibility to borrow people, who can be, for example, victims of hate speech or activists in combating hate speech, instead of books.

India has rich traditions of performing arts which has been source of syncretism and peaceful coexistence since centuries. In the context, Venkaiah Naidu, the Vice President of India (2018) points out, "The rich tradition of Indian music and art must be understood in the context of Indian life and thought that promotes the concepts of harmony and integration. In the Indian world view, art is an integral and important part of human existence and adds value to the quality of human lives."
"India has a great tradition of music from ancient period to the present time. The Indian classical music and arts represent India's cultural glory. Our art and dance forms act as bridge between the value systems of ancient India and the new generation. They represent the eternal and everlasting principles of life that promote discipline, obedience and peaceful coexistence.... Over the years, theatre has played a key role in influencing public opinion on contemporary issues."

He further points out, "All such forms of Indian art and music form part of our rich culture and play a key role in unifying the country and its' people."

Hence, performing arts can be sites where performers can bring in diverse perspectives questioning the narratives of hate and mount credible counter narratives which can be catalysts for a culture of peace. When such initiatives strategically use nonviolent communication to construct messages, these performing arts can actually contribute to enhanced solidarity, longing for reconciliation and a spirit of mutual coexistence.

\section{Integrating Nonviolent Communication in Performing Arts}

Martin and Varney (2003) notes, "Communication is fundamental to nonviolent action, centrally in the sense that nonviolent action is itself a form of communication and secondarily in the role of communication to coordinate nonviolent resistance and win over third parties."

In this context, it could be underlined that communication is central to any acts of nonviolence or in other words all efforts to promote nonviolence is part of the communication process.

While not much work has been done in analyzing nonviolent action or endeavours through the lenses of communication theories, historically, there have been abundant nonviolent initiatives where communication has been the centrifugal force. For instance, Martin (1996) links Gandhi's satyagraha to communication. He notes, "It is possible to go so far as to argue that the essence of satyagraha is communication: whereas violence, as a form of communication, is a monologue, 
nonviolence tries to turn a conflict situation into a dialogue. Although this is only one interpretation of satyagraha, it highlights the close connection between communication and nonviolence. The connection can also be argued directly in terms of a Gandhian theory of nonviolent communication."

Martin (1996) further points out how Gandhi used his strategies of nonviolent communication in his campaigns. He points out:

Gandhi was always careful to first try conventional channels, such as making polite requests of officials to change their policies which were causing suffering or lack of freedom. If this did not work, he would then, quite openly, initiate a campaign utilizing nonviolent methods, such as marches, boycotts, or undertaking illegal activities. These methods might be interpreted as a form of coercion, albeit nonviolent coercion. Gandhi, though, conceived nonviolent action as a method of conversion, of "melting the heart" of the opponent. When the oppressors saw the suffering that was willingly accepted by the nonviolent activists-known as satyagrahis--they would recognize the satyagrahis' commitment to their cause and be converted to it.

Gandhi's successful use of nonviolent communication as a method of conversion of the oppressor underlines its criticality in handling narratives of hate. In fact, to shape any narrative, whether hatred or love and compassion, communication is the central element. While one requires great skills to make hate speech viral, constructing meaningful nonviolent communication which can bring people together also requires ingenuity.

Gandhi's nonviolent communication can be argued to have great symbolism. In this context, Sharma (2019) quoting Johny ML, an art curator and critic who, in 2010, co-curated an exhibition titled 'Freedom to March: Rediscovering Gandhi through Dandi' with Anubhav Nath, director, Ojas Art Gallery points out, "Gandhi was a great performance artist by default; his actions and lifestyle were highly symbolic and artistic. He was also a complex personality, which artists over the years have deconstructed in their own ways, spawning a wide variety of work with different points of view. Each time he is deconstructed, he throws open the possibilities of reconstruction too." Chakravarty (1995) eloquently talks about the incredible reach of Gandhi's usage of nonviolent communication:

Gandhi left out no means and no technique to rouse the consciousness of the people and instil into them the imperative of their active participation in the movement...The means to convey that message were often primitive, but no medium available at the time was left out. From traditional interpersonal meansincluding the travelling bards- the bauls of Bengal, for instance - to the educated student going out on literacy-cum-swadeshi missions- the composing of patriotic songs and setting up choirs in villages, mohallas and bustees, to the immortal magic lantern, nothing was left out. It was a gigantic operation, sustained through the ups and downs of the freedom struggle, and later on followed by the handwritten posters and graffiti.

Chakravarty's description of Gandhi's use of different forms of communication which ensured that no medium available at that time of India's freedom struggle was left untouched underlines the efficacy of nonviolent communication in reaching out to the masses. Right from the bauls of Bengal to the setting up village choirs composing patriotic songs- all were used to propagate the Mahatma's message.

Gandhi's nonviolent communication comprises of nonviolent speech and action, flexibility, openness and mutual respect. The overarching goal of development of human relationships and human values - all these were part of the performances during the freedom struggle which inspired Indians all across the country.

Here it may be mentioned that communication has multiple functions including informational, command or instructive, persuasive, education, entertainment and development. As performing arts are different forms of communication, all these functions are relevant for performances too. So, when messages of nonviolence, love and compassion are ingrained in performing arts, they can play an important role in persuading the masses against 
Integrating Nonviolent Communication in Performing Arts to Counter Narratives of Hate 자탄

hatred and can contributing to raising popular sentiments for social harmony. It can also help in educating the public while fulfilling its function of entertainment. Gandhi's nonviolent communication which underlines the spirit of flexibility, openness and nonviolent speech and action was a powerful tool in educating the Indians during the freedom struggle and helped in raising popular sentiments. Gandhi with his adherence to truth provided Indians with facts; his nonviolent communication was a powerful model of instructive function of communication wherein it guided Indians during the freedom struggle on what to do and how to act.

It is not just India's freedom struggle, but also other nonviolent movements across the world highlight on how one can use nonviolent communication and how it can be broadly practiced where conflicts crop up and in which people wish to use nonviolent alternatives to resolve disputes and differences.

At this point, it would be pertinent to look at on what constitutes nonviolent communication. According to senior Gandhian, Natwar Thakkar (Kundu, 2018):

\section{To me nonviolent communication literacy would mean how our communication efforts should be nonviolent; how our ability and capacity to communicate not only with ourselves but with our family and society be nonviolent in all aspects and overall how the entire process of communication whether between individuals, groups, communities and the world at large should be nonviolent in nature.}

Thakkar also underlines the role of nonviolent communication in emotional bridge building. He notes (Kundu, 2018), “Nonviolent communication literacy would automatically help in strengthening and deepening relationships. When we are able to emotionally build bridges with others, we will be able to empathize with their views."

Further Marshall Rosenberg has talked about nonviolent communication being founded on language and communication skills that strengthen our ability to remain human, even under trying conditions.

The different elements of nonviolent communication include: nonviolent speech and action, use of appropriate and positive language, mutual respect, empathy, compassion, importance of gratitude, avoidance of stereotypes and evaluative language. All these elements portray positive messages and can be useful to promote attitudinal and behavioural changes amongst people.

The different elements of nonviolent communication when used in the construction of communication messages helps in healthy fulfilment of its function. For instance, the use of appropriate and positive language can help in instructing the audience on efficacy of mutual coexistence. Use of empathy in communication messages can help in fulfilling the role of persuasion in a positive way. Language of compassion can help build bridges wherever there are fissures. Avoidance of stereotypes and evaluative language can pave way for reconciliation and forgiveness.

So, for instance, when a theatre performance tries to promote inter-faith harmony by integrating different elements of nonviolent communication, it tries to encourage a new narrative mutual coexistence. An important goal of nonviolent communication is emotional bridge building and this can help in building bridges between warring faiths if they are in conflict. Such strategies in performing arts can be used adroitly to reduce the deficit in trust and helps in relationship building.

In times of conflicts, listening to music can be an important therapeutic activity. In fact, music permeates different aspects of individual's lives. Whether music is instrumental or has lyrics, it helps in capturing and reinforcing emotional experiences. It is a great unifier as it allows individuals and societies to relate to one another beyond their differences. As several studies indicate that empathy can be triggered through our senses, songs with appropriate lyrics and music can help in evoking empathy. Also, studies show on how music performances through acoustic fluctuations and sound intensity can actually aid in impacting the emotional response of the listeners. Hence, lyrical content which integrates different elements of nonviolent communication can contribute in 
influencing mood, thoughts and behaviours of the listeners.

Similarly, street plays could be developed by student groups on different themes by integrating different elements of nonviolent communication.

\section{CONCLUSION}

This chapter while delving the important role of performing arts in promoting peace and reconciliation in societies argued on the need to integrate nonviolent communication in performances. Nonviolent Communication is an important strategy in nonviolent conflict resolution; it helps in emotional bridge building and developing connections. In societies which are facing turmoil and conflicts, performing arts which integrates nonviolent communication can provide a healing touch and reconciliation. It also furthers the important functions of communication namelyinformational, instructive, persuasive, educational and entertainment and aids in social harmony. In this backdrop, it can be argued that exposure and training in nonviolent communication is significant for those involved in performing arts. Constant research needs to be done on how to effectively integrate elements of nonviolent communication in performances.

\section{REFERENCES}

Bailey, Alison. 2019. The Art of Peace: The Value of Culture in Post-Conflict Recovery; The British Council.

Chakravarty, Nikhil. 1995. Mahatma Gandhi: The Great Communicator; Gandhi Marg, pp. 393.
Council of Europe. 2018. Campaign examples. In: Council of Europe. [online] Available at: www.coe. int/en/web/no-hate-campaign/campaign examples 1\#\{\%2226873630\%22:[17]\}; accessed on February 5, 2020

Guterres, António. 2019. Hate speech 'on notice' as UN chief launches new plan to 'identify, prevent and confront' growing scourge; https://news.un.org/en/ story/2019/06/1040731?fbclid=IwAR3w47T4 -2tpu8G fl8IE8c4tJIM27JfwbOXvV1CI-nlLsJujyb4MPA96HOo

Kundu, Vedabhyas. 2018. Nurturing Emotional Bridge Building: ADialogue with Nagaland's Gandhi; Peaceworks; 8(1): 100-109.

Martin, Brian. 1996. Communication Technology and Nonviolent Action; Communication Technology and Nonviolent Action; Media Development; 43(2): 3-9.

Martin, Brian and Varney, Wendy. 2003. Nonviolence Speaks: Communicating against Repression; Cresskill, NJ: Hampton Press; 2003.

Naidu-Silvermann, Ereshnee. 2015. The Contribution of Art and Culture in Peace and Reconciliation Process in Asia; Centre for Culture and Development, Copenhagen, Denmark.

Naidu, Venkaiah. 2018. Art and dance forms act as bridge between the value systems of Ancient India and the New Generation; https://pib.gov.in/newsite/PrintRelease. aspx?relid=186077 (accessed on November 17, 2019)

Sharma, Manoj. 2019. Portraying the Artists of Nonviolence; https://www.hindustantimes.com/cities/portraying-anartist-of-non-violence/story-y2stb60aILjFchSPnT5KYM. html ; (accessed on November 19, 2019) 